\title{
Girardilainen kirjavaaka
}

Eeva Rohas 
eskityn kirjoituksessani kirjallisuudentutkimuksen ikiaiheeK seen: kysymykseen kaunokirjallisuuden tehtävästä sekä kaunokirjallisen teoksen arvon märitttymisen perustasta.

Tämä kysymys on askarruttanut minua hiljattain aivan erityisestä näkövinkkelistä toimiessani, kirjailijan työni lomassa, vierailevana päätoimittajana Kulttuurintutkimus-lehden syksyllä ilmestyneessä René Girard -teemanumerossa. Tällöin tuli ajankohtaiseksi pohtia Girardin monen tieteenalan piiriin versonutta mutta alun perin kirjallisuudentutkimuksesta ponnistanutta mimeettistä teoriaa tarkemmin siltä kannalta, mikä on sen väite kaunokirjallisuudesta ja kaunokirjallisuuden tehtävästä.

Mimeettinen teoria on karkeasti kiteytettynä teoria inhimillisen halun jäljittelevästä luonteesta, väkivallan synnystä mimeettisen halun sivutuotteena sekä ihmisyhteisön keinoista torjua yhteisöä hajottavaa vastavuoroista väkivaltaa syntipukkimekanismin keinoin, missä väkivaltaiset jännitteet kanavoidaan ja puretaan sopivan uhrin tuntomerkit täyttävään, marginaalista sattumanvaraisesti valittuun yksilöön tai ryhmään. Kolmiosaiseksi hahmotetun teorian viimeisessä, teologisesti virittyneessä osassa Girard lisäksi esittää ehdotuksensa evankeliumien potentiaalista syntipukkimekanismin paljastajina ja lakkauttajina.

Teorian ensimmäinen osa, psykologisesti orientoitunut kuvaus mimeettisestä halusta, löytyy vuonna 1961 ilmestyneestä teoksesta Mensonge romantique et la vérité romanesque, joka englanninnoksena sai nimen Deceit, Desire, and the Novel (1976/1966). Siinä aineistona toimii kaunokirjallisuus, jota Girard lukee mimeettisen halun kannalta. Tässä yhteydessä Girard ensi kerran esittää teoriansa siitä, miten välittäjän eli mallin ja tämän seuraajan välille muodostuu ihailun ja vihan ohjailema kilpailusuhde. Myöhemmissä teoksissaan La violence et le sacré (1972; Väkivalta ja pyhä, suom. Olli Sinivaara, Tutkijaliitto 2004) ja Les choses cachées depuis la fondation du monde (1978; Things Hidden since the Foundation of the World, 1987) Girard täydentää ja laajentaa teoriaansa kulttuurin alkunäyttämölle asti.

Perustarpeiden tultua tyydytetyiksi subjekti ei Girardin mukaan lakkaa haluamasta vaan etsii tässä vaiheessa halulleen jonkin vetovoimaisen mallin, jonka halun kohteita alkaa itsekin tavoitella. Halu on jäljiteltyä, toiselta omaksuttua, ja sen tosiasiallinen kohde on välittäjä, malli, ei mallin ja seuraajan yhteisesti tavoittelema objekti. Mallin ja seuraajan välinen etäisyys määrittää, miten raivoisa kilpailusuhteesta muodostuu; ulkoisessa välityksessä kilpailijat eivät koskaan kohtaa toisiaan, mutta modernissa maailmassa yleistyneen sisäisen välityksen tapauksessa malli ja seuraaja ovat (sosiaalisessa mielessä) lähellä tosiaan ja kateus ja sen myötä syntyvät väkivaltaiset jännitteet rehottavat.

Esittäessään perustan teorialleen - joka, sivumennen sanoen, vaatimattomasti pyrki lopulta selittämään koko inhimillisen kulttuurin perustan ja sen keskeiset, Girardin universaaleiksi väittämät toimintamekanismit - Girard tulee piilevämmin ilmaisseeksi myös oman käsityksensä kirjallisuudesta ja sen arvon perustasta. Tässä puntarissa kieli ja sen uudistaminen tai muotokokeilut 


\section{Kyse on vain ja ainoastaan siitä, ettei taiteen pidä olla minkään aatejärjestelmän orja.}

eivät paljoa paina. Itse asiassa kaikki yksilöllisyys tai omaperäisyyteen pyrkiminen on lähinnä haitaksi, koska sellainenhan mitä ilmeisimmin lukeutuu Girardin parjaaman, ainutlaatuisuuden illuusiota kannattelevan romanttisen harhan piiriin. Kaunokirjallisen teoksen ansiokkuutta arvioitaessa Girardin vaa'assa painaakin ainoastaan loppuratkaisu sekä - siihen kytkeytyen - teoksen sanoma.

Tämänkaltaisessa arvottamisen tavassa tekstin referentiaalinen funktio painottuu poeettisen funktion kustannuksella. Girardin määritelmässä "suuri romaani" on nimittäin sellainen, jossa metafyysinen halu voitetaan ja päähenkilö tajuaa olevansa vihaamansa ja halveksimansa Toisen kaltainen. Vertikaalinen ero subjektin ja hänen Toisensa välillä paljastuu illusoriseksi: he ovat itse asiassa yksi ja sama, toistensa peilikuvia.

Kun kaunokirjallisessa teoksessa päädytään tällaiseen lopputulemaan, teoksen sanoman kauneutta ja oikeamielisyyttä ei kukaan voine kiistää. En kuitenkaan liene ainut, joka ei lähtisi suosittelemaan Girardin lähestymistapaa romaanitaiteen arvottamisen mittapuuksi tai ohjenuoraksi kirjailijalle. Muis$\tan$ Laura Lindstedtin todenneen romaaninsa Ystäväni Natalia (Teos, 2019) ilmestymisen aikaan, että kaunokirjallisuus on ideologioiden ja merkitysten purkutyömaa. Se on mielestäni hyvin sanottu - ja haastaa tehokkaasti girardilaisen näkökulman, joka nähdäkseni viime kädessä tähtää kristillisen sanoman eteenpäin viemiseen. Lindstedtinkään muotoilusta ei kannattane tehdä universaalia sääntöä, olisihan se paradoksaalistakin ajatuksen sisällön huomioon ottaen. Mutta jos pitäisi valita vaihtoehtojen "ideologioiden purkutyömaa" ja "ideologian äänitorvi" väliltä, minäkin nimeäisin taiteen ihannerooliksi näistä ensimmäisen.

Sillä taiteelle ei ole olemassa valmiita totuuksia? Tai koska totuus, tiedettykin, pitää taiteessa löytää yhä uudelleen? Kenties lopulta, kun näiden kysymysten parissa tarpeeksi piehtaroi, on myös todettava, ettei taidetta (näin ollen) ole ilman romanttista harhaa. Olisi harhaista muuta edes olettaa. 
Jo alkaneen kirjasyksyn kaunokirjallista satoa tutkaillessani en etsi luettavaa aiheen perusteella - kieli ratkaisee. Lisäksi haluan oivaltaa uutta, saada jotain pureskeltavaa. Jotain, mikä tihkuu sivuja sormeilevan lukijan tajuntaan, tekee tahmaiseksi, niin että kun itse alan taas kirjoittaa, aavistus luetusta tarttuu omaan näppäimistööni.

Girardin toivomaa valmiiksi pureskeltua, kristillisen maailmankuvan läpäisemää loppuratkaisua en kirjoilta toivo. Eikä syynä ole se, että mielestäni sellaisen läsnäolo tekisi teoksesta automaattisesti suuren sijasta päinvastoin surkean. Kyse on vain ja ainoastaan siitä, ettei taiteen pidä olla minkään aatejärjestelmän orja.

Lopuksi on toisaalta kysyttävä, voiko purkutyömaa-ajattelun ulottaa aivan kaikkiin ideologioihin. Onko kaunokirjallisuuden oltava ideologioiden purkutyömaa myös suhteessa vaikkapa feminismiin? Mitä tästä seuraa feminismille ja toisaalta, jos kirjoittaja päättää lähteä kirjoittamaan juuri feministisesti virittynyttä kaunokirjallista tekstiä, mitä se tarkoittaa lopputuloksen kannalta? Onko tällaisilla alkuasetuksilla syntynyt kirjoitus jotenkin huonompaa taidetta tai jopa jotain aivan muuta kuin taidetta - propagandaa? Tätä kirjoittaessani olen lähdössä kesällä perustetun feministisen esseen verkoston (FEVER) tapaamiseen. Taidanpa heittää kysymykseni ilmoille myös siellä. Ja taidanpa esittää nämä kysymykset myös Lauralle, kun Jyväskylässä syyskuussa Maailmantuskafestivaalien aikaan haastattelen häntä Kirjailijatalolla.

Ja sen jälkeen onkin varmasti aika taas kirjoittaa, sillä pahoin pelkään, että tulevat vastaukset avaavat yhä uusia kysymyksiä. Tai ei, en minä pelkää, vaan toivon. 